
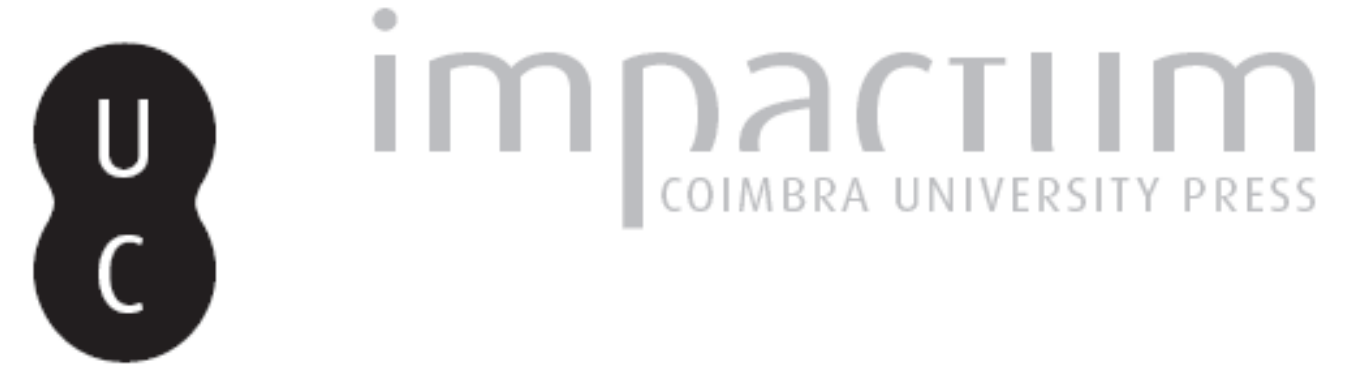

\title{
Comments on Roochnik's "Residual ambiguity in Plato's Statesman"
}

\author{
Autor(es): Harvey, George
}

Publicado por: Imprensa da Universidade de Coimbra

URL persistente:

URI:http://hdl.handle.net/10316.2/42237

DOI:

DOI:https://doi.org/10.14195/2183-4105_5_2

Accessed : $\quad$ 26-Apr-2023 10:56:54

A navegação consulta e descarregamento dos títulos inseridos nas Bibliotecas Digitais UC Digitalis, UC Pombalina e UC Impactum, pressupõem a aceitação plena e sem reservas dos Termos e Condições de Uso destas Bibliotecas Digitais, disponíveis em https://digitalis.uc.pt/pt-pt/termos.

Conforme exposto nos referidos Termos e Condições de Uso, o descarregamento de títulos de acesso restrito requer uma licença válida de autorização devendo o utilizador aceder ao(s) documento(s) a partir de um endereço de IP da instituição detentora da supramencionada licença.

Ao utilizador é apenas permitido o descarregamento para uso pessoal, pelo que o emprego do(s) título(s) descarregado(s) para outro fim, designadamente comercial, carece de autorização do respetivo autor ou editor da obra.

Na medida em que todas as obras da UC Digitalis se encontram protegidas pelo Código do Direito de Autor e Direitos Conexos e demais legislação aplicável, toda a cópia, parcial ou total, deste documento, nos casos em que é legalmente admitida, deverá conter ou fazer-se acompanhar por este aviso.

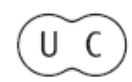




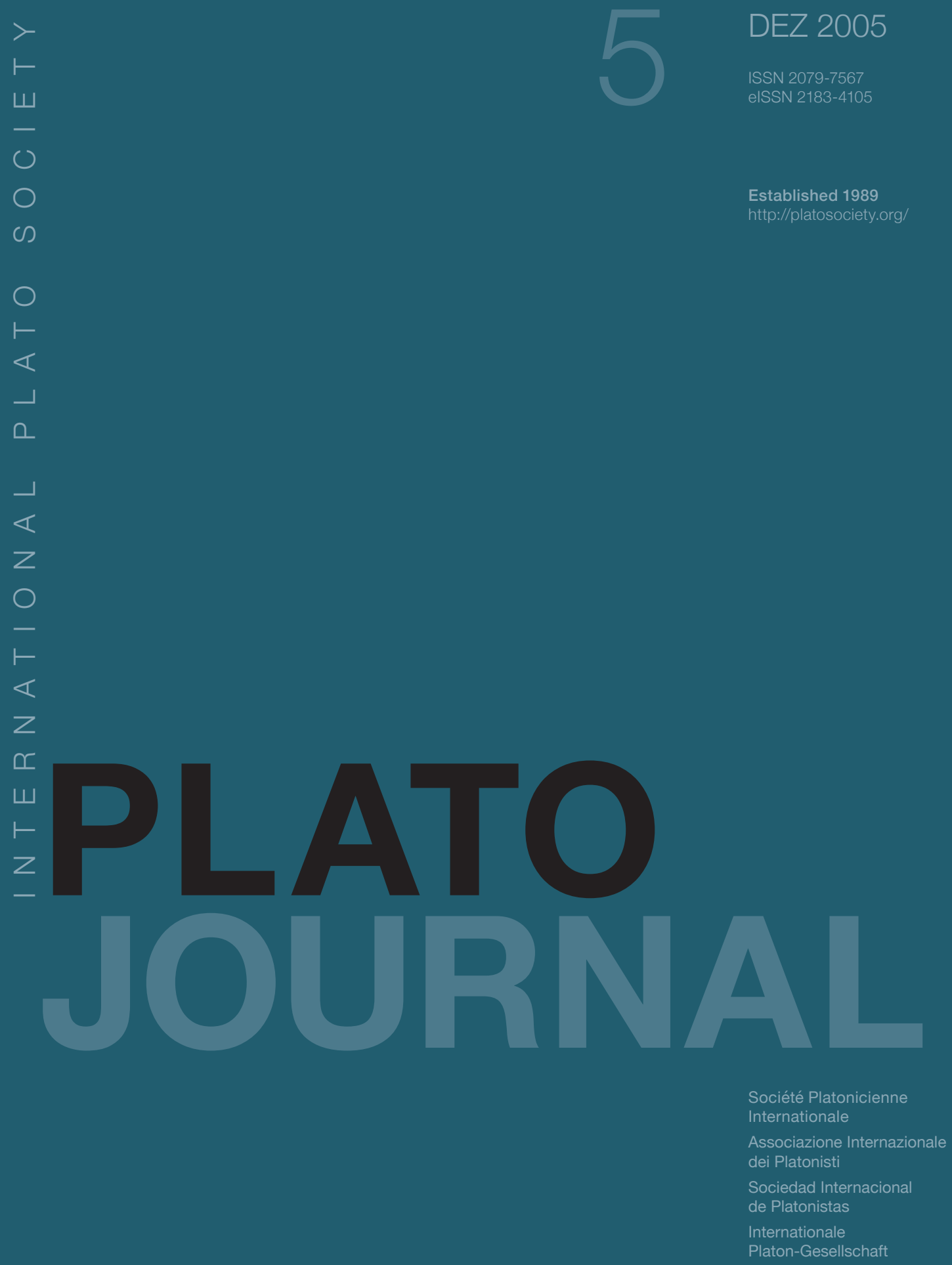




\section{COMMENTS On RoOchniK’s “REsiduAl AMBigUity in Plato’s STATESMAN”}

David Roochnik suggests that in the Statesman, it is possible to trace a thread of residual and ineliminable ambiguity that extends throughout the dialogue, starting from the initial characterization of statesmanship as a theoretical art to the Eleatic Stranger's remarks about democracy. In the suggestion that this thread of residual ambiguity is one of the Statesman's teachings, we are presented with an original perspective on Plato's thought. This is because, in the Statesman, it is suggested that all that is required in order to give an account of the finest and greatest things is the ability to apply the method of division correctly to the subject matter in question. While care must be taken in equating the Stranger's views with Plato's, the presence of residual ambiguities that represent important elements of the dialogue's teaching raises questions about the extent to which Plato himself is committed to the notion that reality can be rendered intelligible when subjected to the right kind of philosophical scrutiny.

The paper begins with a description of the dual condition of under- and overdetermination of written texts. The hermeneutical situation one finds with all great books is magnified in the case of Platonic dialogues, just because they are dialogues, featuring sparse text, the use of images, myths, and other dramatic elements that allow the same text to support a multiplicity of meanings. David Roochnik points to a number of passages in various dialogues that reveal an awareness of this very condition on the interlocutors' part, especially in passages pertaining to important philosophical doctrines, the adequate treatment of which require a more extensive discussion than the confines of the dialogues allow. It is here, however, that questions arise about Roochnik's thesis. He begins by characterizing the ambiguities in Plato as examples, albeit prime examples, of the kinds of ambiguities that are associated with a reader's encounter with any text, but also considers self-acknowledged cases of under-determination as open to five other possible explanations. His suggestion is that the ambiguities one encounters in the Statesman are best explained by the fifth possibility, namely, that they are a central element of the dialogue's (and Plato's) teaching. It is not clear, however, that we are given the resources to determine whether the ambiguities one encounters in the Statesman can be considered residual and not explained by any combination of the alternative possibilities. This is especially true of the Statesman, where the interlocutors take great care to avoid excessive digression, and make the reader aware that the inadequate examination of certain topics has more to do with the stated aim of adhering to standards of measure and proportion in producing an account (see 286b-c) than with the truth about the topics themselves. Notable examples of this include the Stranger's refusal to explain the difference between form and part that serves as the basis for proper division (262c; 263a-b), as well as the postponement of a precise examination of the nature of due measure on the grounds that what has been said is sufficient for present purposes (284bd). It may, however, be due to the very nature of textual ambiguity that there is no conclusive way of deciding which explanation is best, and it is perhaps for this reason that Roochnik never goes beyond the point of making suggestions.

Difficulties also arise in light of the suggestion that the three points of ambiguity Roochnik discusses constitute a thread running throughout the dialogue. I will consider 
each of the three points as sources of residual ambiguity before remarking on their places in the dialogue's overall structure. The first has to do with the seemingly inconsistent treatment of the art of statesmanship as an intellectual rather than a productive art. This early determination does not sit well with the later associations of statesmanship with practical activity such as at 305d and 308c-d. Roochnik rejects Campbell's position that statesmanship as a "commanding science" is both independent of practice and yet stands in some immediate relation to the practical. I think that the apparent ambiguity in the treatment of statesmanship as either intellectual or practical can be resolved by noting the peculiar way in which these kinds of knowledge are defined, and that Campbell's interpretation comes closer to describing what Plato might have had in mind.

First, I do not think the first division of arts sets productive arts apart from nonproductive. While the practical arts are characterized in part by the "bringing into being of bodies that were not before” (258d6-8), this characterization begins by describing this type of knowledge as inherently present in practical actions. By contrast, intellectual arts are not described as non-productive, but rather by reference to the fact that these sorts of expertise do not involve practical actions, and only provide knowledge (258d4-6). That practical activity, and not production, is the basis for the division is supported by the fact that statesmanship is determined to be "more closely related" to the intellectual side of the division than to the "manual or generally practical sort" (259c10-d2) simply because it does not involve the use of hands or the body, and that ruling is achieved through the understanding and force of the mind (259c6-8). The difference between an intellectual and practical art seems therefore to rest on whether the art's characteristic activities are physical or psychic in nature. In this way, an intellectual art can be said not to involve practical actions in the narrow sense of not being bound up with physical activity, but can still be related to practice by having some sphere of practical activity that is its unique domain (289d). This seems to be required by the very notion of arts concerned with the direction and control of other experts, since all direction is done for the sake of bringing something into being (261b).

On the other side of the division, it is far from clear that in intellectual (gnõstikai) arts, we are concerned with theoretical knowledge in something like the Aristotelian sense. The Stranger's use of the former, instead of the latter, might reflect the intention to place greater emphasis on the acquisition of knowledge through the formulation of judgments rather than on the transparent relationship of a knowing subject seeing an object as it really is. That the psychic activity of making judgments characterizes the whole of intellectual arts is supported by the next division: all intellectual arts either stop with the judgments they make, or have the additional task of giving instructions to others (260a-b). What is common to calculating and directing arts, and therefore to the whole of intellectual arts, is the activity of making judgments. I will only suggest here that emphasis on the activity of forming judgments as characteristic of all intellectual arts might also anticipate the later distinction between arts of measurement, where the division between relative measurement and the art of due measure can be read as picking up on the distinction between judgments made purely for the sake of knowledge acquisition and those made for the sake of producing "all the good and fine things the various arts produce” (284a-b). The division between practical and intellectual arts that 
begins the search for the statesman, therefore, does not seem to set the Aristotelian conception of theory apart from production. Rather, we see that practical arts are defined narrowly by reference to whether manual activity is or is not involved, and that intellectual arts are never described as producing knowledge in an un-intrusive or disinterested manner, since many of those arts have the stated aim of producing goods. If I am right about the peculiar features of the characterizations of these kinds of art, then much of what may appear as an ambiguity can be resolved.

According to David Roochnik, the distinction between intellectual and productive arts carries with it important ramifications for the very possibility of theoretical understanding. In it, we are faced with the question of whether the theoretical attitude allows us to see the world as it really is, or is irreducibly intrusive. This is certainly a major philosophical issue, and while I do not think the division between intellectual and practical arts touches upon this problem, I agree that we do confront this question in the Statesman in its use of the method of division. The method itself seems to undergo modification in the course of the dialogue, starting as a process of dividing forms down the middle to one where division along the natural joints is only achieved on the basis of having first seen all the relevant likenesses and un-likenesses. But even in the Stranger's explicit reference to the rule governing division, he uses language suggesting that collection requires the activity of "penning-in" all related things into a single kind (285b). The Stranger's description of the rule, in light of the difficulties thus far encountered in generating an account of the statesman, suggests that it involves the kind of "stamping" that seems to undermine the notion that philosophical inquiry leaves the objects under examination intact. Much depends, naturally, on how seriously we take this stampingmetaphor in Plato (and whether the discussion of an ontologically-grounded method in the Philebus clarifies matters), but what is striking about the Statesman as well as the Sophist is the extent to which philosophy is regarded as at least in large part a productive activity. In the Sophist, the critical distinction is between production of images that either maintain or distort the proportions found in the original; to the extent that the sophist is shown to be an expert in distortion, the unstated implication is that philosophy can be described (though perhaps not defined) as the production of likenesses (i.e., accounts) that maintain the correct proportions. The Statesman highlights the need to produce accounts that are not merely commensurate with the truth, but are also somehow measured in their own right.

As for the ambiguity identified with the Stranger's description of democracy, I cannot say I am convinced that it is one that constitutes a thread along with the other two. Except for reference to the Myth of the Reversed Cosmos, no evidence is offered to support the claim that the ambiguity relating to democracy has anything to do with the ambiguities relating to the distinction between theory and production, or the method of division. David Roochnik seems to think that the residual ambiguity emerges when considered against the backdrop of the Myth, where the political constitutions exist only in an age of increasing disorder. According to Roochnik, increasing disorder has the effect over time of rendering lawful regimes lawless, with the implication being that democracies are to be evaluated in light of these conditions. More needs to be said about why increase in disorder at the cosmic level leads to the inevitable abandonment of law in 
cities. Another way of interpreting the political implications of the Myth is that instead of abandoning law, regimes over time stubbornly preserve the laws in the face of greater change and variance in human affairs. Much of the Stranger's concern in the latter sections of the dialogue have to do not with regimes becoming lawless, but rather with their maintaining laws simply for the sake of being lawful, even to the point where those laws become oppressive and ultimately destructive. If we evaluate democracy on this interpretation of the Myth, we are faced with the question of whether lawless democracies are better than monarchies governed not by tyrants, but by bad laws. The extent to which the Stranger can be said to defend democracy will depend on how we answer this question, but here again, we might say that the text is under-determined in spelling out just what the political implications of the Myth are.

It should be evident from the preceding remarks that I do not see an ongoing thread running from the dialogue's opening divisions to its later treatment of political constitutions. Instead, I see the Myth of the Reversed Cosmos as serving as the source of the Statesman's ambiguities relating to both philosophy and politics, rather than as lending only supporting evidence. In the Myth, we find a larger context in which we can relate both politics and philosophy to the conditions of our present cosmic age. It is because of the absence of direct divine guidance that humans are in need of political constitutions, and receive from the gods the desire to teach and learn, desires necessary for philosophy, and absent from the Age of Cronus. In bringing our attention to an aspect of the Statesman that warrants further exploration, David Roochnik's paper makes a considerable contribution in helping us to appreciate the complexity of Plato's later philosophy. An examination that begins by considering what Plato sees as symptoms of human existence in the Age of Zeus will build upon the achievements of this paper.

George HARVEY

University of Texas - Pan American 